\title{
The Use of Problem Based Learning Assisted by Treasure Maps to Improve Creativity and Mathematics Learning Outcomes
}

\author{
Mentari Wulanmay \\ SD Harapan Bangsa \\ mentariwulanmay09@gmail.com
}

\section{Article History}

received 3/12/2020

revised 17/12/2020

accepted $31 / 12 / 2020$

\begin{abstract}
The purpose of this research is to increase the creativity and learning outcomes of students in mathematics. To achieve the goal, the researcher used Classroom Action Research which was carried out in two cycles at Harapan Bangsa Elementary School. Data analysis techniques are qualitative and quantitative descriptions. The results of the research in the first cycle of creativity which was 4 were 11 students. In cycle II the average creativity increased, namely 30 students or $100 \%$ got an average of 4 . Before being given the complete learning action, it was $46 \%$ or 14 students. After being given an action using the Problem Based Learning model assisted by a treasure map in the first cycle, the learning completeness increased to $77 \%$ or 23 students. In the second cycle, classical mastery of learning increased to $80 \%$ or 24 students. The increase in creativity and student learning outcomes is due to the teacher using the Problem Based Learning model well. Based on the results of the study, it is suggested to the principal to provide training in contemporary methods.
\end{abstract}

Keywords: problem based learning, creativity, learning outcomes

\begin{abstract}
Abstrak
Tujuan penelitian untuk meningkatkan kreativitas dan hasil belajar peserta didik pada pelajaran matematika. Untuk mencapai tujuan, peneliti menggunakan Penelitian Tindakan Kelas yang dilaksanakan dalam dua siklus di SD Harapan Bangsa. Teknik analisis data adalah deskripsi kualitatif dan kuantitatif. Hasil penelitian pada siklus I rata-rata kreativitas yang $\geq 4$ terdapat 11 peserta didik. Pada siklus II rata-rata kreativitas meningkat yaitu 30 peserta didik atau $100 \%$ mendapat rata-rata $\geq 4$. Sebelum diberikan tindakan ketuntasan belajar adalah $46 \%$ atau 14 peserta didik. Setelah diberikan tindakan menggunakan model Problem Based Learning berbantuan peta harta karun pada siklus I ketuntasan belajar meningkat menjadi $77 \%$ atau 23 peserta didik. Pada siklus II ketuntasan klasikal belajar meningkat mencapai $80 \%$ atau 24 peserta didik. Peningkatan kreativitas dan hasil belajar peserta didik dikarenakan guru menggunakan model Problem Based Learning dengan baik. Berdasarkan hasil penelitian maka disarankan kepada kepala sekolah untuk memberikan pelatihan metode kontenporer.
\end{abstract}

Kata kunci: problem based learning, kreativitas, hasil belajar

Social, Humanities, and Education Studies (SHEs): Conference Series https://jurnal.uns.ac.id/shes

p-ISSN 2620-9284

e-ISSN 2620-9292 


\section{PENDAHULUAN}

Matematika adalah ilmu tentang pola dan urutan. Menurut James dan James (1976) dalam kamus matematika yang ditulisnya menyatakan bahwa matematika adalah ilmu tentang logika mengenai bentuk, susunan, besaran, dan konsep-konsep yang saling berhubungan satu sama lain yang terbagi dalam tiga bidang yaitu aljabar, analisis dan geometri. Anak usia SD antara 7-11 tahun menurut Piaget memasuki tahap operasional konkret. Kemampuan yang tampak pada tahap ini adalah kemampuan dalam proses berfikir untuk mengoperasikan kaidah-kaidah logika, meskipun masih terikat dengan obyek yang bersifat kongkret. Anak usia SD memiliki karakteristik sebagai berikut : senang bermain, senang bergerak, senang bekerja dalam kelompok dan senang merasakan atau melakukan sesuatu secara langsung.

Standart Proses Satuan Pendidikan Dasar dan Menengah (Permendiknas no.41 tahun 2007), salah satu komponen dalam rencana pelaksanaan pembelajaran adalah kegiatan atau langkah-langkah pembelajaran yang terdiri dari tiga tahapan yaitu pendahuluan, inti dan penutup. Pendahuluan adalah waktu untuk mengajak peserta didik memfokuskan perhatian dan memotivasi, dilanjutkan dengan kegiatan inti yang merupakan inti proses pembelajaran. Pada tahapan tersebut diharapkan aktivitas belajar peserta didik melalui proses eksplorasi, elaborasi, dan konfirmasi. Adapun pada penutup adalah menyimpulkan atau merangkum, menilai sebagai bentuk refleksi, memberikan umpan balik dan tindak lanjut. Dalam kegiatan inti guru hendaknya menggunakan model pembelajaran yang tepat, sehingga peserta didik mampu berpikir logis, analitis, sistematis, kritis, dan kreatif serta bekerjasama.

Namun pada kenyataan dilapangan banyak guru mengajar menggunakan metode ceramah. Media pembelajaran yang tersedia disekolah tidak digunakan secara maksimal, guru hanya menggunakan buku dalam proses pembelajaran. Guru tidak menggunakan alat peraga yang menarik. Dalam proses belajar mengajar peserta didik pasif karena siswa hanya duduk diam mendengarkan. Siswa lebih suka berbicara dengan temannya dibandingkan mendengarkan guru mengajar. Ketika dihadapkan pada masalah matematika, peserta didik mempunyai daya kreativitas rendah dalam menyelesaikan dan memecahkan masalah matematika. Akibatnya nilai peserta didik tidak memenuhi KKM. Hal ini disebabkan guru kurang tepat dalam menggunakan model pembelajaran.

Berdasarkan keadaan dilapangan maka dibutuhkan model pembelajaran Problem Based Learning untuk meningkatkan daya kreativitas dan hasil belajar peserta didik. Model pembelajaran Problem Based Learning adalah suatu model pembelajaran yang menghadapkan peserta didik pada tantangan "belajar untuk belajar" (Duch, 1995). Lebih lanjut Duch menyatakan bahwa model pembelajaran Problem Based Learning dimaksudkan untuk mengembangkan peserta didik berpikir kritis, analitis, dan untuk menemukan serta menggunakan sumber daya yang sesuai untuk belajar. Model ini sangat cocok digunakan untuk meningkatkan daya kreativitas dan hasil belajar peserta didik. Karena model pembelajaran Problem Based Learning mempunyai kelebihan yaitu: 1) peserta didik dapat belajar, mengingat, menerapkan, dan melanjutkan proses belajar secara mandiri. 2) Peserta didik diperlakukan sebagai pribadi yang dewasa. Perlakuan ini memberikan kebebasan kepada peserta didik untuk mengimplementasikan pengetahuan atau pengalaman yang dimiliki untuk memecahkan masalah.

Menurut uraian latar belakang masalah, maka peneliti tertarik untuk mengadakan penelitian tidakan kelas dengan judul "Penggunaan Model Problem Based Learning Berbantuan Peta Harta Karun untuk Meningkatan Daya Kreativitas dan Hasil Belajar Matematika pada Peserta Didik Kelas IV SD Harapan Bangsa Semester II Tahun Pelajaran 2019 - 2020"

Tujuan dalam penelitian ini adalah untuk mendiskripsikan model Problem Based Learning berbantuan peta harta karun dalam upaya meningkatkan daya kreativitas 
siswa kelas IV SD Harapan Bangsa. Serta meningkatkan hasil belajar siswa kelas IV SD Harapan Bangsa.

\section{METODE}

Penelitian ini merupakan penelitian tindakan kelas, karena penelitian ini dilakukan untuk memecahkan pembelajaran dikelas. Rancangan model ini menggunakan penelitian tindakan kelas dari Kemmis dan Taggart, yaitu yang berbentuk spiral dari siklus satu kesiklus berikutnya. Setiap siklus meliputi planning (rencana), action (tindakan), observation (pengamatan), dan reflection (refleksi).

Penelitian dilakukan di kelas IV SD Harapan Bangsa yang dilaksanakan pada semester II Tahun 2019 - 2020, yaitu pada bulan April 2020. Subjek dalam penelitian ini adalah seluruh peserta didik kelas IV SD Harapan Bangsa. Yang berjumlah 30 peserta didik, 13 laki-laki dan 17 perempuan.

Penelitian ini terdiri dari dua variabel. Variabel bebas $(X)$ adalah variabel yang mempengaruhi, dalam hal ini adalah penggunaan model pembelajaran Problem Based Learning berbantuan peta harta karun. Variabel terikat $(\mathrm{Y})$, adalah variabel yang dipengaruhi, dalam hal ini adalah kreativitas dan hasil belajar matematika.

Rencana tindakan dalam penelitian ini akan dilaksanakan dalam 2 (Dua) siklus dan direncanakan akan dilaksanakan dengan langkah-langkah sebagai berikut: perencanaan, tindakan, observasi, dan refleksi. Teknik yang digunakan dalam mengumpulkan data adalah observasi, tes, dan dokumentasi. Instrumen yang digunakan dalam penelitian ini adalah lembar observasi dan soal evaluasi..

\section{HASIL DAN PEMBAHASAN}

Pada kondisi awal guru kelas IV SD Harapan Bangsa masih menggunakan metode ceramah. Hal ini terlihat ketika proses belajar mengajar berlangsung guru mendominasi dalam pembelajaran, peserta didik hanya mendengarkan penjelasan dari guru dan di akhir pembelajaran guru memberi soal latihan. Hasilnya banyak peserta didik yang hasil belajarnya belum tuntas, yang disebabkan oleh kurangnya kreativitas peserta didik dalam menyelesaikan masalah atau soal. Peserta didik tidak mampu menumbuhkan ide-ide baru dalam menyelesaikan masalah. Selain itu peserta didik juga tidak mampu mengembangkan pengetahuan yang dimiliki untuk menyelesaikan masalah. Ketuntasan klasikal belajar peserta didik kelas IV pada pelajaran Matematika hanya $46 \%$ dengan nilai rata-rata 57,7 . Hal ini belum sesuai dengan tujuan yang akan dicapai pada Kriteria Ketuntasan Minimal (KKM) yaitu 68. Hasil belajar pelajaran Matematika dapat di amati pada tabel berikut:

Tabel 1. Ketercapaian Hasil Belajar Peserta didik Pada Kondisi Awal

\begin{tabular}{cccc}
\hline Hasil Belajar & Frekuensi & Prosentase & Indikator \\
\hline$\geq 68$ & 14 & $46 \%$ & $\begin{array}{c}80 \% \text { peserta } \\
\text { didik mendapat } \\
\text { nilai } \geq 68\end{array}$ \\
\hline$<68$ & 16 & $54 \%$ & \\
\hline
\end{tabular}

Dari tabel 1 tampak prosentase peserta didik yang nilainya $\geq 68$ sebelum diadakan tindakan hanya $46 \%$ atau 14 peserta didik dan $54 \%$ atau 16 peserta didik nilainya $<68$. Rendahnya hasil belajar Matematika peserta didik kelas IV SD Harapan Bangsa disebabkan oleh guru kurang kreatif dalam pembelajaran, model pembelajaran yang digunakan kurang bervariasi serta kurang melibatkan peserta didik. Akibatnya kurang kurang kreatif dalam menyelesaikan masalah. Selain itu, peserta didik dalam mengikuti pembelajaran Matematika tidak berani bertanya. Sebagian peserta didik tidak dapat menjawab pertanyaan guru, hanya tertentu yang aktif dalam pembelajaran.

Analisis data hasil belajar pra siklus, maka peneliti melaksanakan penelitian dengan menggunakan model Problem Based Learning berbantuan peta harta karun. 
Penelitian dilaksanakan selama 2 siklus, siklus I dilaksanakan dalam 3 pertemuan dan siklus II dilaksanakan dalam 2 pertemuan dengan penerapan model Problem Based Learning berbantuan peta harta karun untuk meningkatkan daya kreativitas dan hasil belajar siswa dalam pembelajaran Matematika.

Hasil refleksi yang dilakukan oleh peneliti terhadap penggunaan model Problem Based Learning berbantuan peta harta karun pada mata pelajaran matematika SD Harapan Bangsa menunjukkan hasil yang memuaskan meskipun masih ada yang belum sesuai dengan apa yang diharapkan. Hasil refleksi pada siklus I sebagai berikut:

1) Hasil penilain kegiatan yang dilakukan guru dalam pembelajaran menggunakan model Problem Based Learning berbantuan peta harta karun mengalami peningkatan pada setiap pertemuan.

2) Hasil rata-rata daya kreativitas peserta didik meningkat pada setiap pertemuan setelah melakukan pembelajaran dengan model Problem Based Learning berbantuan peta harta karun yaitu kreatif dalam menyelesaikan soal dan aktif dalam pembelajaran. Tetapi secara keseluruhan rata-rata daya kreativitas peserta didik belum mencapai indikator penelitian. Hasil penelitian daya kreativitas siswa selama mengikuti pembelajaran menggunakan model Problem Based Learning pada siklus I tersaji pada tabel 2 dibawah ini :.

Tabel 2. Hasil Penilaian Kreativitas Peserta Didik Pada Siklus I

\begin{tabular}{cccc}
\hline $\begin{array}{c}\text { Hasil } \\
\text { Kreativitas }\end{array}$ & Frekuensi & Prosentase & Indikator \\
\hline$\geq 4$ & 11 & $37 \%$ & $\begin{array}{c}80 \% \text { peserta } \\
\text { didik } \\
<4\end{array}$ \\
19 & $63 \%$ & $\begin{array}{c}\text { mendapat nilai } \\
\text { rata - rata } \geq 4\end{array}$ \\
\hline
\end{tabular}

3) Terjadi perubahan hasil belajar setelah melakukan pembelajaran dengan model Problem Based Learning berbantuan peta harta karun. Perubahan hasil belajar tersaji pada gambar 1 di bawah ini:

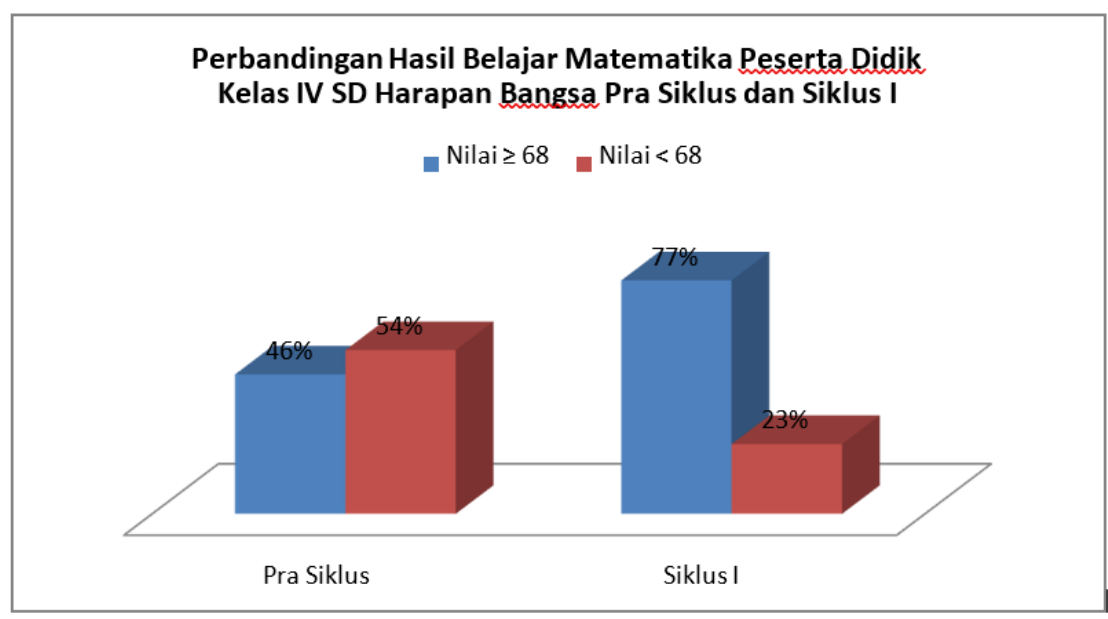

Gambar 1. Diagram Perbandingan Hasil Belajar Matematika Peserta Didik Kondisi Awal dan Siklus I

Pada siklus I daya kreativitas siswa meningkat tetapi belum mencapai indikator keberhasilan. Hasil belajar meningkat tetapi belum mencapai indikator keberhasilan. Kegiatan guru dalam menggunakan model Problem Based Learning berbantuan peta harta karun sudah mencapai indikator keberhasilan. Berdasarkan hasil tindakan, maka penelitian dilanjutkan pada siklus II. 
Hasil refleksi yang dilakukan oleh peneliti terhadap peningkatan hasil belajar dan daya kreativitas pertemuan pertama menggunakan model Problem Based Learning berbantuan peta harta karun pada mata pelajaran matematika kelas IV SD Harapan Bangsa menunjukkan hasil yang lebih baik. Pembelajaran yang dilaksanakan menggunakan model Problem Based Learning berbantuan peta harta karun pada siklus II meningkat yaitu dari 4,31 menjadi 4,60. Nilai daya kreativitas pada pertemuan II siklus II meningkat yaitu 4,60 dibandingkan pertemuan I siklus II nilai daya kreativitasnya 4,31. Peserta didik lebih aktif dalam bekerja kelompok dan kreatif dalam menyelesaikan soal atau masalah. Hasil penelitian kreativitas peserta didik selama mengikuti pembelajaran menggunakan model Problem Based Learning berbantuan peta harta karun pada siklus II tersaji pada tabel 3 di bawah ini:.

Tabel 3. Hasil Penilaian Kreativitas Peserta Didik Siklus II

\begin{tabular}{cccc}
\hline $\begin{array}{c}\text { Hasil } \\
\text { Kreativitas }\end{array}$ & Frekuensi & Prosentase & Indikator \\
\hline$\geq 4$ & 30 & $100 \%$ & $\begin{array}{c}80 \% \text { peserta } \\
\text { didik mendapat } \\
\text { nilai rata - rata } \geq \\
4\end{array}$ \\
\hline
\end{tabular}

Pada pertemuan II siklus II hasil belajar peserta didik meningkat yaitu 24 peserta didik atau $80 \%$ siswa tuntas. Perbandingan hasil belajar peserta didik pada siklus I dan siklus II tersaji pada gambar 4.4 di bawah ini

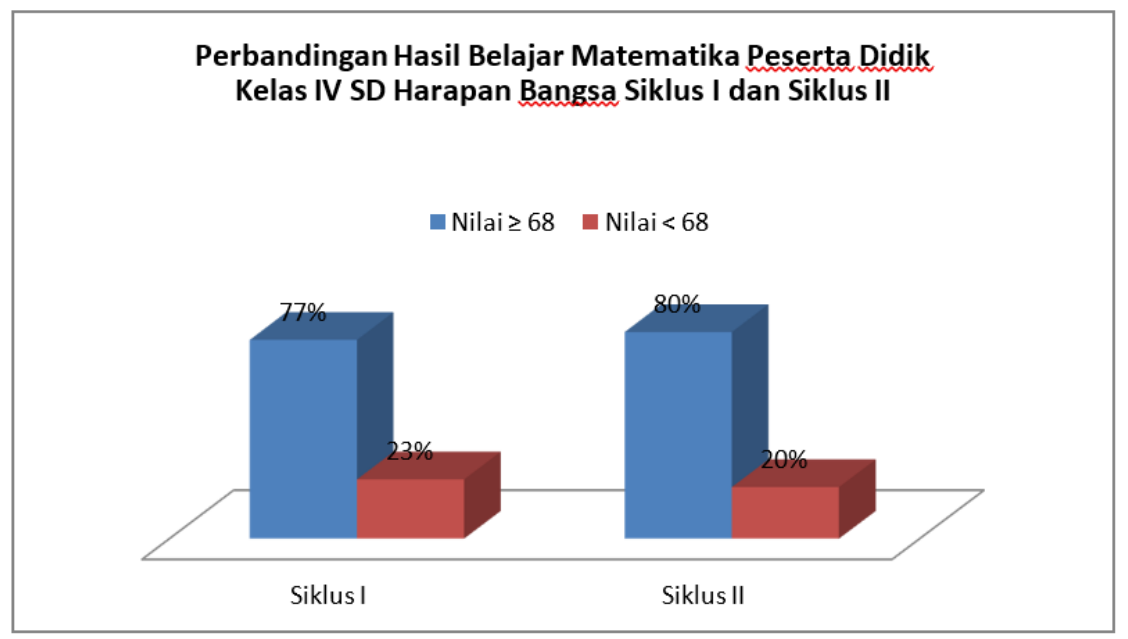

\section{Gambar 2. Diagram Perbandingan Hasil Belajar Matematika Pada Siklus I dan Siklus II}

Dilihat dari tabel di atas nilai kreativitas peserta didik pada siklus I sampai dengan siklus II mengalami peningkatan. Nilai rata-rata day kreativitas pada siklus I yang $\geq 4$ terdapat 11 peserta didik atau $37 \%$. Pada siklus II nilai rata-rata kreativitas meningkat drastis yaitu 30 peserta didik atau 100\%. Dapat disimpulkan pembelajaran matematika menggunakan model Problem Based Learning berbantuan peta harta karun dapat meningkatkan daya kreativitas siswa. Jika dilihat dari keseluruhan data yang diperoleh, dapat dikatakan kreativitas peserta didik pada siklus berhasil atau meningkat. Perbandingan nilai rata-rata kreativitas peserta didik pada siklus I dan siklus II disajikan pada gambar di bawah ini. 


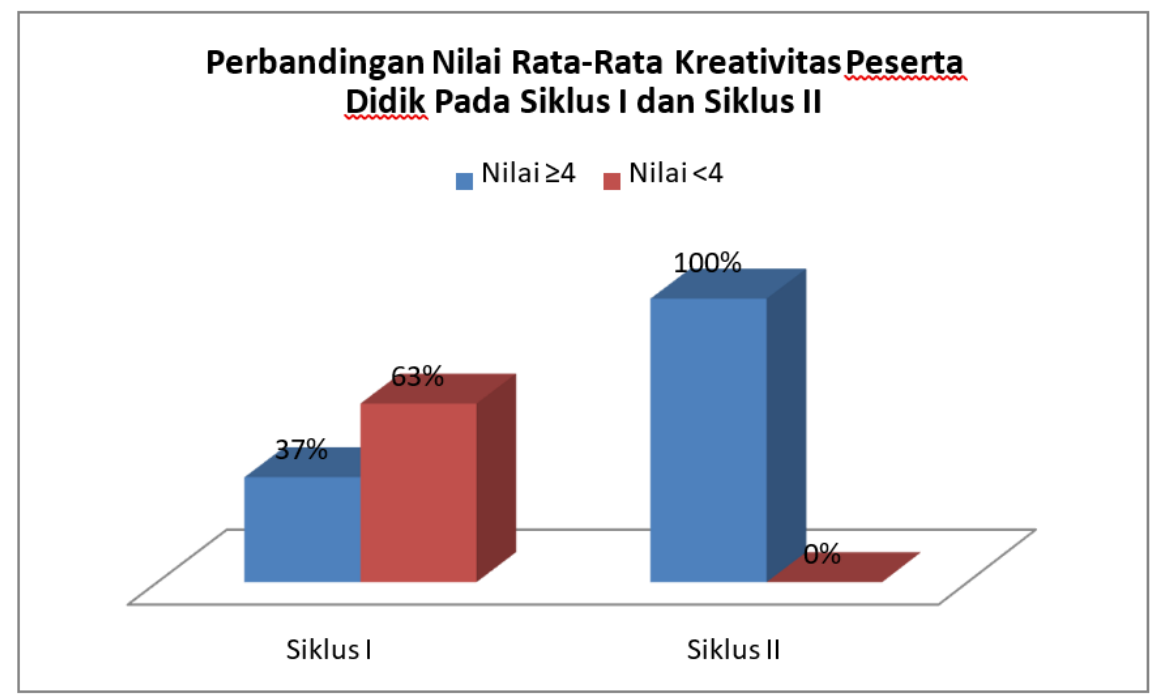

Gambar 3. Perbandingan Nilai Rata-Rata Kreativitas Peserta Didik Pada Siklus I dan Siklus II

Setelah diamati dan dicatat oleh guru, hasil belajar peserta didik kelas IV SD Harapan Bangsa pada pelajaran matematika materi sifat-sifat bangun ruang dan jarring - jaring bangun ruang diperoleh data di bawah ini:

Tabel 4. Perbandingan Hasil Belajar Matematika Pada Kondisi Awal, Siklus I dan Siklus II

\begin{tabular}{cccccccc}
\hline $\mathbf{N}$ & $\begin{array}{c}\text { Ketunta } \\
\text { o }\end{array}$ & \multicolumn{2}{c}{ Pra Siklus } & \multicolumn{2}{c}{ Siklus 1 } & \multicolumn{2}{c}{ Siklus 2 } \\
& $\begin{array}{c}\text { Frekue } \\
\text { nsi }\end{array}$ & $\begin{array}{c}\text { Prosent } \\
\text { ase }\end{array}$ & $\begin{array}{c}\text { Frekue } \\
\text { nsi }\end{array}$ & $\begin{array}{c}\text { Prosent } \\
\text { ase }\end{array}$ & $\begin{array}{c}\text { Frekue } \\
\text { nsi }\end{array}$ & $\begin{array}{c}\text { Prosent } \\
\text { ase }\end{array}$ \\
\hline 1 & $\geq 68$ & 14 & $46 \%$ & 23 & $77 \%$ & 24 & $80 \%$ \\
2 & $<68$ & 16 & $54 \%$ & 7 & $23 \%$ & 6 & $20 \%$ \\
& Jumlah & 30 & $100 \%$ & 30 & $100 \%$ & 30 & $100 \%$ \\
\hline
\end{tabular}

Dari tabel 4 dapat dilihat bahwa ada kenaikan hasil belajar dari pra siklus sampai siklus II. Nilai yang diatas KKM dari pra siklus 14 atau $46 \%$ meningkat pada siklus I menjadi 23 peserta didik atau 77\%. Dari siklus I meningkat lagi pada siklus II menjadi 24 peserta didik atau $80 \%$ dari 30 peserta didik.

Dengan hasil tersebut maka diambil saran bahwa pembelajaran menggunakan model Problem Based Learning berbantuan peta harta karun dapat meningkatkan kreativitas dan hasil belajar peserta didik kelas IV SD Harapan Bangsa. Terjadinya hipotesis tindakan dalam penelitian ini membuktikan bahwa penerapan model Problem Based Learning dapat meningkatkan kreativitas peserta didik dan hasil belajar matematika. Sesuai dengan kelebihan model pembelajaran Problem Based Learning yaitu peserta didik dapat belajar, mengingat, menerapkan, dan melanjutkan proses belajar secara mandiri. Peserta didik diperlakukan sebagai pribadi yang dewasa. Perlakuan ini memberikan kebebasan kepada peserta didik untuk mengimplementasikan pengetahuan atau pengalaman yang dimiliki untuk memecahkan masalah.

\section{SIMPULAN}

Berdasarkan analisis data yang telah dibahas dalam penelitian, dapat disimpulkan bahwa: penggunaan model Problem Based Learning berbantuan peta harta karun dapat meningkatkan kreativitas dan hasil belajar peserta didik kelas IV SD Harapan Bangsa.

1) Pada siklus I nilai rata-rata kreativitas yang $\geq 4$ terdapat 11 peserta didik. Sedangkan pada siklus II nilai rata-rata kreativitas meningkat yaitu 30 peserta didik atau $100 \%$ peserta didik mendapat nilai rata-rata $\geq 4$. 
2) Selain itu penggunaan model Problem Based Learning berbantuan peta harta karun dapat meningkatkan hasil belajar peserta didik kelas IV SD Harapan Bangsa. Sebelum diberikan tindakan ketuntasan belajar peserta didik adalah $46 \%$ atau 14 peserta didik. Setelah diberikan tindakan menggunakan model Problem Based Learning berbantuan peta harta karun pada siklus I ketuntasan belajar peserta didik meningkat menjadi $77 \%$ atau 23 peserta didik. Sedangkan pada siklus II ketuntasan klasikal belajar peserta didik meningkat mencapai 80\% atau 24 peserta didik.

Berdasarkan hasil penelitian tindakan pada kelas IV SD Harapan Bangsa ada beberapa saran antara lain: sekolah yang guru-gurunya masih menggunakan metode konvensional maka Kepala Sekolah dapat memberikan pelatihan metode - metode pembelajaran yang kontenporer bagi guru dan guru dapat menggunakan model Problem Based Learning berbantuan peta harta karun untuk meningkatkan kreativitas dan hasil belajar peserta didik..

\section{DAFTAR PUSTAKA}

Akbar, Esa Dhuhur Putra. (2012). Penggunaan Pendekatan Matematika Realistik Pada Pembelajaran Matematika Topik Bangun Ruang Untuk Meningkatkan Hasil Belajar Matematika Bagi Siswa Kelas IV SD Negeri Sidorejo Lor 05 Kecamatan Siderejo Kota Salatiga, Skripsi. Salatiga. PGSD Universitas Kristen Satya Wacana

Arifin, Zainal. (2012). Evaluasi Pembelajaran. Bandung: PT Remaja Rosdakarya Offset.

Asmani, Jamal, Ma'mur. (2010). 7 Tips Aplikasi PAKEM. Jogjakarta: Diva Press.

Asrori, Mohammad. (2009). Psikologi Pembelajaran. Bandung: CV Wacana Prima

Beetlestone, Florence. (2012). Creative Learning: Strategi Pembelajaran Untuk Melesatkan Kreativitas Siswa. Bandung: Nusa Media.

Djamarah, Syaiful, Bahri. (2011). Psikologi Belajar. Jakarta: PT Rineka Cipta.

Heruman. (2013). Model Pembelajaran Matematika di Sekolah Dasar. Bandung: PT Remaja Rosdakarya

Ibrahim dan Suparni. (2012). Pembelajaran Matematika Teori Dan Aplikasinya. Yogyakarta: Suka Press UIN Sunan Kalijaga

Riyanto, Yatim. (2010). Paradigma Baru Pembelajaran: Sebagai Referensi Bagi Guru/Pendidik Dalam Implementasi Pembelajaran Yang Efektif Dan Berkualitas. Jakarta: Kencana Prenada Media Group

Sani, Ridwan, Abdullah. (2013). Inovasi Pembelajaran. Jakarta: PT Bumi Aksara

Sugiyono (2013). Metode Penelitian Pendidikan Pendekatan Kuantitatif, Kualitatif dan $R \& D$. Bandung: Alfabeta

Susanto, Ahmad. (2013). Teori Belajar dan Pembelajaran di Sekolah Dasar. Jakarta: Prenadamedia Group

Tampubolon, Saur. (2014). Penelitian Tindakan Kelas: Sebagai Pengembangan Profesi Pendidik dan Keilmuan. Jakarta: Erlangga

Trianto. (2011). Mendisain Model Pembelajaran Inovatif Progresif. Jakarta: Kencana

Trianto. (2011). Model Pembelajaran Inovatif Berorientasi Kontruktivistik. Jakarta: Prestasi Pustaka

Vitasari, Rizka. (2012). Peningkatan Keaktifan Dan Hasil Belajar Matematika Melalui Model Problem Based Learning Siswa Kelas V SD Negeri 5 Kutosari. Skripsi. Surakarta: FKIP PGSD Universitas Sebelas Maret.

Wulandari, Eni. (2011). Penerapan Model PBL (Problem Based Learning) pada Pembelajaran IPA Siswa Kelas V SD. Skripsi. Surakarta: FKIP Universitasa Sebelas Maret. 